\title{
Crystalloid podocytopathy with focal segmental glomerulosclerosis in PCM: a case report
}

You La Jeon ${ }^{1}$, Woo In Lee ${ }^{1 *}$, Yujin Choi ${ }^{1}$, So Young Kang ${ }^{1}$, Myeong Hee Kim', Sung-Jig Lim² and Sang Ho Lee ${ }^{3}$

\begin{abstract}
Background: Crystalloid podocytopathy with focal segmental glomerulosclerosis in plasma cell myeloma (PCM) is rare. Case Presentation: We present a case of crystalline deposition in the bone marrow (BM) and various renal cells with only proteinuria as a symptom. As workup for proteinuria, a renal biopsy sample was obtained. EM showed multiple crystalline depositions in renal tubular cells and podocytes. Focal segmental glomerulosclerosis with crystalloid podocytopathy was diagnosed. Because monoclonal gammopathy was detected in the serum and urine, a BM study was also performed. Plasma cells with needle-shaped inclusion bodies were observed. The crystalline deposits in the plasma cells and podocytes were positive for Masson's trichrome and kappa light-chain staining. These findings indicated that the crystalline deposits originated from paraprotein. The case showed a rare process of focal segmental glomerulosclerosis via crystalline deposition in podocytes in plasma cell myeloma.
\end{abstract}

Conclusions: Crystalloid podocytopathy is a likely cause of renal damage such as FSGS in PCM, although it is an uncommon mechanism for myeloma kidney.

Keywords: Plasma cell myeloma, Crystalline deposition, Focal and segmental glomerular sclerosis, Podocytopathy, Tubulopathy, Bone marrow

\section{Background}

Monoclonal proteins may take various shapes and forms, such as immunoglobulin (Ig) aggregates, amyloid substances, or even crystalline deposits. In particular, in the rare cases, crystalline deposition can be found in plasma cell myeloma (PCM) as initial presentation of the disease or as a complication in the bone marrow (BM), kidney, or other organs [1]. Occasionally, intracellular crystalline deposition has been found in myeloma cells and histiocytes among BM hematopoietic cells [2]. The kidneys are more rarely affected with macrophages, glomerular cells, or proximal tubular cells [3, 4]. Furthermore, reports of cases involving crystalline deposition in podocytes (or glomerular visceral epithelial cells) are extremely rare [5]. Here, we report a rare case of focal segmental glomerulosclerosis (FSGS) wherein multiple crystalline inclusions were seen in BM plasma cells and tubular epithelial cells and podocytes in the kidney in a patient with PCM.

\footnotetext{
* Correspondence: wileemd@khu.ac.kr

'Department of Laboratory Medicine, School of Medicine, Kyung Hee University and Kyung Hee University Hospital at Gangdong, 892, Dongnam-ro, Gangdong-gu, Seoul 134-727, Republic of Korea Full list of author information is available at the end of the article
}

\section{Case presentation}

A 52-year-old woman was referred to a nephrologist for work-up of proteinuria and slightly increased serum creatinine levels found during a routine health examination. The patient had been aware of her proteinuria for 2 years. However, she had not undergone further evaluation or treatment. The patient had no other relevant medical history.

The laboratory results of complete blood count and blood chemistry assay were represented in Table 1. Urinalysis revealed $1+$ protein with normal $\mathrm{pH}$, and the results were negative for glucose. Random urine chemistry showed a state of glomerular proteinuria as the results revealed creatinine level of $1847.56 \mu \mathrm{mol} / \mathrm{L}(20.9 \mathrm{mg} / \mathrm{dL})$, microalbumin level of $0.04869 \mathrm{~g} / \mathrm{dL}(486.9 \mathrm{mg} / \mathrm{L})$, and an albumin/creatinine ratio of $2329.7 \mathrm{mg} / \mathrm{g}$. The protein level in the 24-h urine sample was elevated to $2.62 \mathrm{~g}$. The patient was then found to have a monoclonal protein concentration of $5.2 \mathrm{~g} / \mathrm{L}$ in serum and $0.01 \mathrm{~g} / \mathrm{L}$ in urine. The serum and urine monoclonal protein fractions were found to represent IgG and kappa in immune fixation electrophoresis. The free kappa and lambda light-chain levels in the serum were $571.6 \mathrm{mg} / \mathrm{L}$ and $23.3 \mathrm{mg} / \mathrm{L}$, respectively, 
Table 1 The laboratory results of complete blood count and blood chemistry

\begin{tabular}{lll}
\hline The test & Results & Reference range \\
\hline Complete blood count & & \\
WBC count & $4.2 \times 10^{9} / \mathrm{L}$ & $4.0-10.0$ \\
Hemoglobin & $111 \mathrm{~g} / \mathrm{L}$ & $120-160$ \\
Platelet count & $180 \times 10^{9} / \mathrm{L}$ & $350-350$ \\
Blood chemistry & & \\
Protein & $63 \mathrm{~g} / \mathrm{L}$ & $66-83$ \\
Albumin & $33 \mathrm{~g} / \mathrm{L}$ & $35-52$ \\
Creatinine & $115.8 \mu \mathrm{mol} / \mathrm{L}$ & $44.2-79.6$ \\
Calcium & $2.2 \mathrm{mmol} / \mathrm{L}$ & $2.2-2.7$ \\
Phosphorus & $1.1 \mathrm{mmol} / \mathrm{L}$ & $0.8-1.5$ \\
Sodium & $136 \mathrm{mmol} / \mathrm{L}$ & $136-146$ \\
Potassium & $3.8 \mathrm{mmol} / \mathrm{L}$ & $3.5-5.1$ \\
Chloride & $108 \mathrm{mmol} / \mathrm{L}$ & $101-109$ \\
Uric acid & $208.2 \mu \mathrm{mol} / \mathrm{L}$ & $154.7-356.9$ \\
BUN & $5.4 \mathrm{mmol} / \mathrm{L}$ & $2.86-7.14$ \\
Ig G & $12.2 \mathrm{~g} / \mathrm{L}$ & $0.7-1.6$ \\
Ig A & $870 \mathrm{mg} / \mathrm{L}$ & $700-4000$ \\
IgM & $640 \mathrm{mg} / \mathrm{L}$ & $400-2300$ \\
\hline Ab & &
\end{tabular}

Abbreviations: WBC white blood cell, BUN blood urea nitrogen, Ig immunoglobulin

and the serum free light-chain ratio was $24.53(0.26-1.65)$. There was no evidence suggesting hepatitis B or C virus or human immunodeficiency virus infection on serologic tests.

An ultrasound-guided kidney biopsy was performed; the final pathologic diagnosis was FSGS. Among 16 glomeruli, seven showed global sclerosis and two showed segmental glomerulosclerosis (Fig. 1a). Mild tubular atrophy, mild interstitial fibrosis, and focal tubular necrosis were observed. Interestingly, proximal tubular epithelial cells contained some crystalline structures (Fig. 1b). Congo red staining also produced negative results. Interstitial inflammation with mild infiltration of lymphocytes was noted. Immunofluorescence microscopy showed a linear pattern with trace intensity for IgG and a granular pattern for complement component $\mathrm{C} 3(++), \mathrm{Clq}(+)$, and fibrinogen (trace) in the glomerulus (Fig. 2). However, there was no significant positive staining for IgA, IgM, or C4. On performing immunofluorescent staining, the mesangium, tubules, interstitium, and vessels were negative for staining. However, many of the tubular cells showed stronger positivity for the kappa light chain than for the lambda light chain on immunohistochemical staining.

Electron microscopic examination revealed diffuse effacement of foot processes and electron-dense deposits, with some crystalline structures in the cytoplasm of visceral glomerular epithelial cells. Furthermore, similar electron-dense crystalline deposits found in podocytes were observed throughout the cytoplasm of proximal tubular cells (Fig. 1c and d). These showed diverse morphology with a needle shape or a rhomboid shape and variable size ranging from $0.2 \times 1$ to $0.5 \times$ $2.8 \mu^{2}$. However, no pathologic abnormalities were noted within the glomerular basement membrane, mesangium, or glomerular endothelium.

A BM examination was performed to investigate for the presence of plasma-cell neoplasms. The BM aspirate smears were stained with Wright's stain. The plasma cells with fine needle-shaped intracellular crystalline depositions were found to have increased in number, representing up to $10.4 \%$ of the total nucleated cells counted (Fig. 3a). Typical plasma cells were rarely observed. All of the cells with intracellular cytoplasmic crystalline inclusions were negative for $\alpha$-naphthyl acetate esterase (ANBE) staining, suggesting that macrophages such as histiocytes were not involved. The paraffin-embedded BM biopsy and clot sections were stained with hematoxylin and eosin. The cellularity of the BM was 30-40\%, that is, she had normocellular marrow for her age. Cells with red-colored cytoplasmic inclusions and eccentric mononucleosis, which seemed to be malignant plasma cells, were frequently seen in the clot sections (Fig. 3b). Immunohistochemical staining was performed on the BM clot sections with antibodies against CD138, kappa light-chain, and lambda lightchain. Plasma cells stained with CD138 were seen in these sections more frequently than in the aspiration smear. The plasma cells showed strongly positive staining for kappa light-chains (Fig. 3c). However, a few of the plasma cells were positive for lambda light-chain staining. Masson's trichrome staining was performed on clot sections to evaluate the characteristic features of the crystalline deposits. The plasma cells had deep-redcolored cytoplasmic inclusions with fine needle-shaped structures (Fig. 3d). These cells were negative in periodic acid-Schiff staining.

The complex karyotype of 44,X,-X,-6,-21,+mar[2]/ 46,XX[53] was determined by conventional karyotyping using the BM specimen. The fluorescence in situ hybridization studies for detecting cytogenetic abnormalities such as TP53 deletion, 13q14 (RB1) deletion, 1q trisomy, and rearrangement of IgH/MAF - t $(14 ; 16), I g H /$ FGFR3 - $\mathrm{t}(4 ; 14), I G H / C C N D 1-\mathrm{t}(11 ; 14)$ were found to be negative.

\section{Discussion}

A portion of patients with renal disease are diagnosed with PCM [6]. Approximately $60 \%$ of PCM patients have renal failure, and proteinuria can be found in $90 \%$ of these patients [7]. Most of the cases of PCM with renal involvement show myeloma cast nephropathy 


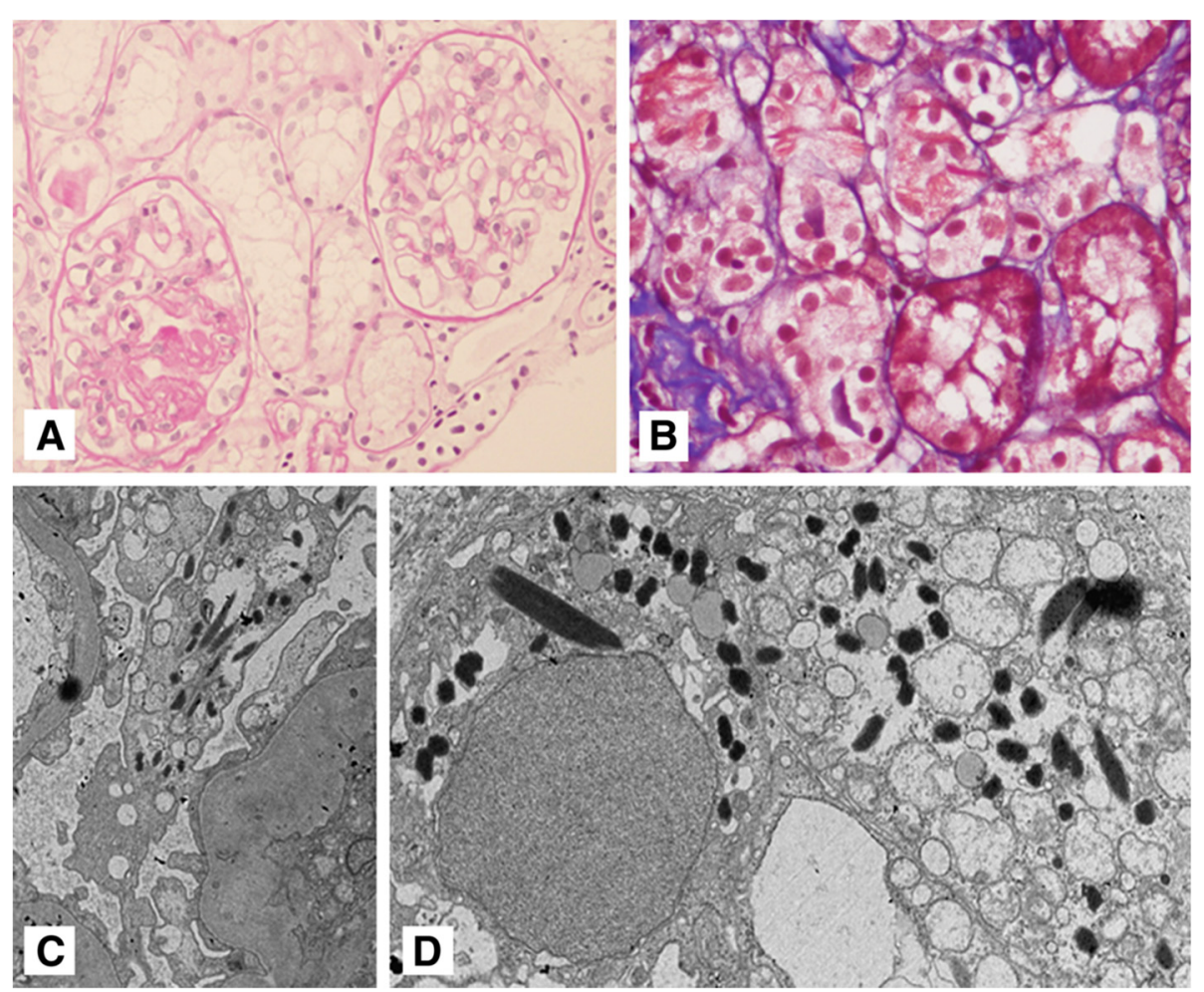

Fig. 1 a Some glomeruli show segmental or global glomerulosclerosis (periodic acid-Schiff stain, $\times 400$ magnification). b Fine needle-shaped crystalline structures in proximal tubular epithelial cytoplasm, which were negative for periodic acid-Schiff staining (Masson's trichrome stain, $\times 400$ ). Crystalline deposition was observed in podocytes (c) and proximal tubular epithelial cells with many large and abnormal lysosomes (d). The morphology of the crystalline structures was diverse and ranged from a needle shape to a rhomboid shape (electron micrograph, original magnification: $\mathbf{c}, \times 5,000 ; \mathbf{d}, \times 6,000)$

(light-chain cast nephropathy) and low-molecular-weight proteinuria [8]. Amyloidosis and monoclonal Ig deposition disease are seen less commonly. Moreover, crystalline deposition is an even more rare presentation. In previous reports, the organs shown to be involved in PCM were the kidneys, skin, liver, lung, spleen, and stomach and various other tissues such as those of the cornea. [9-11]

Except tubular luminal involvement (myeloma cast nephropathy), the main pathologic feature accompanying crystalline deposition in the kidney is light-chainassociated Fanconi syndrome [12]. Light chains secreted by monoclonal plasma cells are reabsorbed by proximal tubular epithelial cells, and on rare occasions, intracellular crystals are formed during this process. These crystals impair tubular function and disrupt overall reabsorption capabilities causing various aggressive symptoms such as glycosuria, aminoaciduria, hyperuricosuria, hyperphosphaturia, and hypercalciuria [13]. In most of these patients, kappa light-chains are typically involved as components of their monoclonal proteins $[14,15]$. The variability subtype Vk1 has the property of resistance to proteolysis by the lysosomal enzyme cathepsin B in tubular epithelial cells [15]. This characteristic of $\mathrm{Vk} 1$ is due to germline mutations of $02 / 012$ or $08 / 018$ [14]. Among these genes, a major mutation of $02 / 012$ induces a nonpolar or hydrophobic residue at position 30 , which represents complementarity-determining region L1 of light chains and forms a portion of the Ig antigen-binding site [13, 14].

Interestingly, our patient showed crystalline deposition in podocytes as well as proximal tubular epithelial cells. Crystalloid podocytopathy is rare, but may occur due to its similar endocytic function of the proximal tubular epithelial cells [16]. Recent studies have reported that in healthy rats, an amount of albumin passes through the glomerular filtration barrier [17]. Podocytes take up albumin and other plasma proteins and process these through degradation or transcytosis [16]. The degradation of albumin occurs in the lysosomes of podocytes [18]. Monoclonal proteins are also considered to be processed in the same manner. If any of these monoclonal proteins are resistant to proteolysis, this may result in crystal formation. Furthermore, the membranous endocytic receptors of proximal tubular epithelial cells, such as megalin, cubilin, and CIC-5, have been found in human podocytes [19].

Podocytopathy caused by crystalline deposits is a very rare phenomenon and only ten cases have been reported 

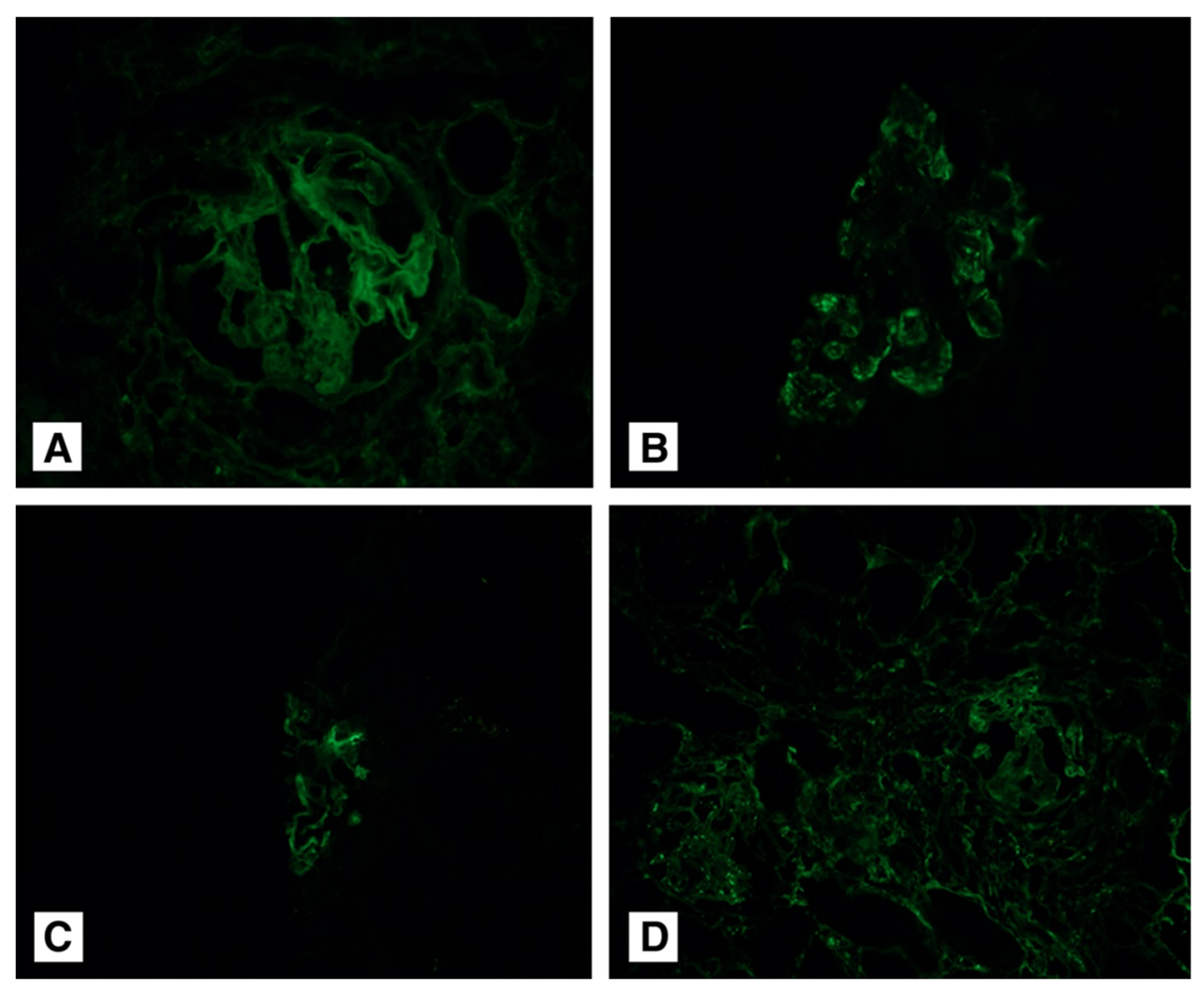

Fig. 2 Immunofluorescence microscopy of the glomerulus. a A linear pattern for $\lg G$ (trace) (x200 magnification). b, c, and d, A granular pattern for complement component C3 (++), C1q (+), and for fibrinogen (trace) (b, x200; c, x100; $\mathbf{d}, \times 100$ magnification)

in the literature so far $[4,5,9-11,20-24]$. The reported cases of crystalloid podocytopathy always involved additional crystalline deposition in other cells in the kidney. Accompanying foot process effacement was common (eight cases out of 11, including the present case), and sclerotic glomeruli implying FSGS was also a common finding (eight cases out of 11). FSGS was considered to occur by crystalloid podocytopathy and paraproteinemia itself in our patient because no other causative factors such as viral infection, drug therapy, or toxins were involved [25]. Proteinuria of various degrees was noted, and over $24 \mathrm{~h}$, the urine protein levels ranged from $0.31 \mathrm{mg}$ to $14.4 \mathrm{~g}$. In this case, the patient presented with glomerular proteinuria, which could be attributed to the crystalline deposition of podocytes.

Although the majority of the cases of podocytopathy caused by crystalline deposits had concurrent tubulopathy (six cases out of 11 had obvious signs of tubulopathy, three cases had no definite description of proximal tubule injury, one case had distal tubulopathy, and one case had no tubulopathy), there was only one case of Fanconi syndrome. Our patient showed only proteinuria with renal insufficiency. It is possible for distributed accumulation of pathologic light-chains in both the glomeruli and tubules to have caused these findings. Such conditions may induce milder impairment of proximal tubular function than sole presentation of proximal tubulopathy.

A morphologically distinguishable feature of this case was the crystalline deposits in BM plasma cells. Among previous cases with crystalloid podocytopathy, only four were described with such findings. Plasma cells may possess crystallized cytoplasmic Ig in their abundant endoplasmic reticulum with various shapes of crystal [2]. The presence of crystalline deposits does not definitively imply the existence of malignant plasma cell dyscrasia because they can also be observed in reactive plasma cells [26]. In fact, the presence of these deposits could be a favorable prognostic finding, along with slow and prolonged disease course, due to the accompaniment of decreased secretion of monoclonal proteins [27]. However, the proportion of patients who had plasma cells with cytoplasmic crystalline deposition in crystalloid podocytopathy (four cases out of 11) or tubulopathy (13 cases out of 57) in a previous study was not low, and the exact duration of these diseases is mostly unknown [14].

\section{Conclusion}

Our patient's sole problem was a proteinuria, besides glomerular proteinuria. Multi-directional clinical, laboratory, and pathologic diagnostic methods contribute to making an accurate diagnosis and understanding pathophysiology. 

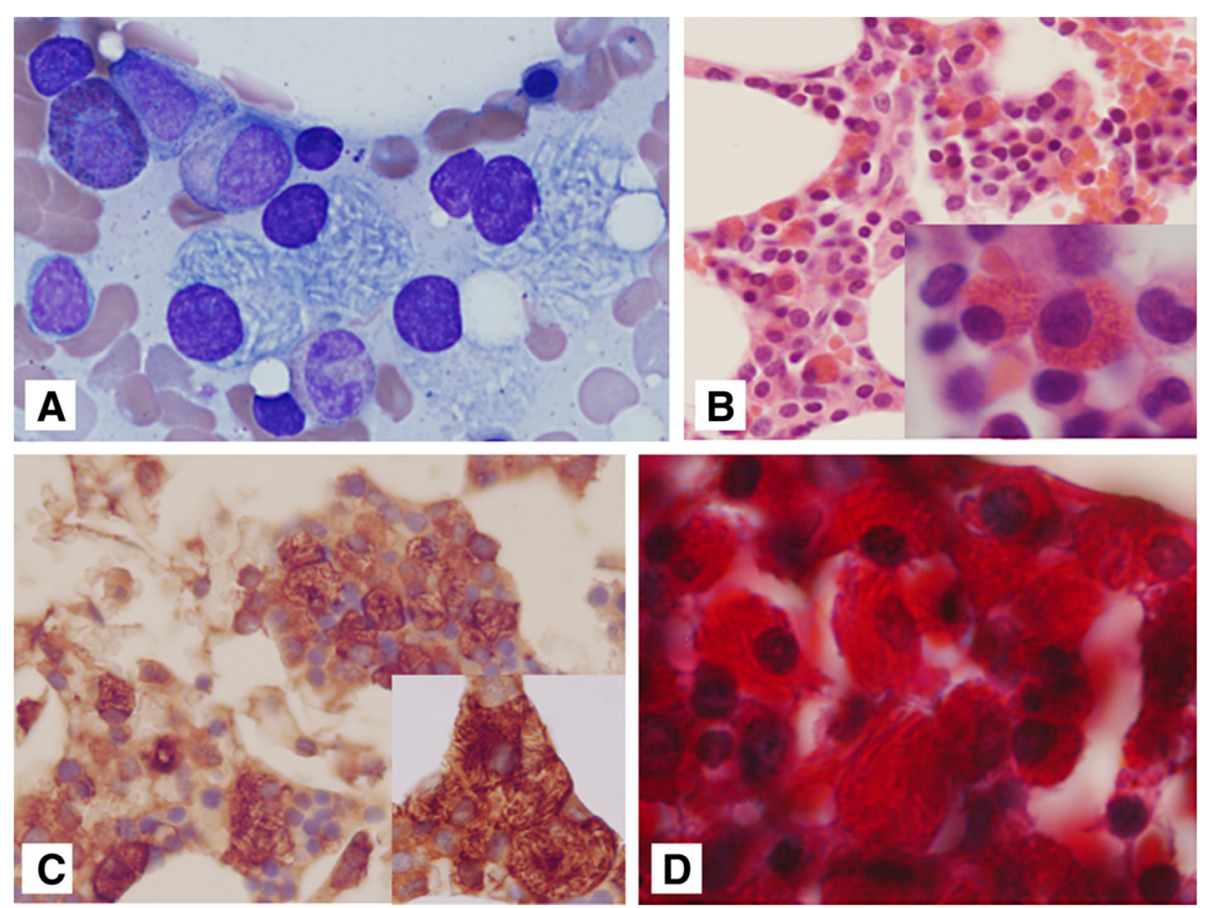

Fig. 3 a Plasma cells with fine needle-shaped intracellular crystalline depositions were frequently seen in the bone marrow (Wright's stain, $\times 1,000$ magnification). b The red-colored cytoplasmic inclusions and eccentric mononucleosis were frequently observed in the clot sections (hematoxylin and eosin staining, (b) $\times 400$ magnification) (inset, $\times 1,000$ magnification). c The plasma cells were stained strongly for the kappa light-chain. Some fine needle-shaped crystalline depositions were also observed in the cells ( $\times 400$ magnification) (inset, $\times 1,000$ magnification). $\mathbf{d}$ The deep-red-colored cytoplasmic inclusions with fine needle-shaped structures considered to be crystalline deposits (Masson's trichrome stain, $\times 1000$ )

Crystalloid podocytopathy is a likely cause of renal damage such as FSGS in PCM, although it is an uncommon mechanism for myeloma kidney. Furthermore, the present case highlights an instance of morphologically and histologically rare findings of crystalline podocytopathy and tubulopathy in the kidney and crystalline deposition in plasma cells in the BM.

\section{Consent}

Written informed consent was obtained from the patient for publication of this Case report and any accompanying images. A copy of the written consent is available for review by the Editor of this journal.

\section{Abbreviations}

BM: Bone marrow; FSGS: Focal segmental glomerulosclerosis;

Ig: Immunoglobulin; PCM: Plasma cell myeloma.

\section{Competing interests}

The authors declare that they have no competing interests.

\section{Authors' contributions}

$Y \sqcup$ drafted the report, contributed to the concept. WIL contributed to the concept and design and approved the final version of the manuscript. YC collected data of the patient. SYK and MHK made relevant corrections. S-JL contributed to reading of renal pathology. SHL contributed to the concept and cared for the patient. All authors read and approved the final manuscript.

\section{Acknowledgements}

None.

\section{Author details}

'Department of Laboratory Medicine, School of Medicine, Kyung Hee University and Kyung Hee University Hospital at Gangdong, 892, Dongnam-ro, Gangdong-gu, Seoul 134-727, Republic of Korea. ${ }^{2}$ Department of Pathology, School of Medicine, Kyung Hee University and Kyung Hee University Hospital at Gangdong, Seoul, Republic of Korea. ${ }^{3}$ Division of Nephrology, Department of Internal Medicine, School of Medicine, Kyung Hee University and Kyung Hee University Hospital at Gangdong, Seoul, Republic of Korea.

Received: 29 July 2015 Accepted: 28 November 2015 Published online: 16 December 2015

\section{References}

1. Molina-Garrido MJ, Guillén-Ponce C, Mora A, Guirado-Risueño M, Molina MA, Molina MJ, et al. Deposition-associated diseases related with a monoclonal compound. Clin Transl Oncol. 2007;9:777-83.

2. Swerdlow SH, Campo E, Harris NL, Jaffe ES, Pileri SA, Stein H, et al. WHO classification of tumours of haematopoietic and lymphoid tissues. 4th ed. Lyon, France: IARC Press; 2008.

3. Lebeau A, Zeindl-Eberhart E, Müller EC, Müller-Höcker J, Jungblut PR, Emmerich B, et al. Generalized crystal-storing histiocytosis associated with monoclonal gammopathy: molecular analysis of a disorder with rapid clinical course and review of the literature. Blood. 2002;100:1817-27.

4. Tomioka M, Ueki K, Nakahashi H, Isoda A, Kuroiwa T, Kaneko Y, et al. Widespread crystalline inclusions affecting podocytes, tubular cells and interstitial histiocytes in the myeloma kidney. Clin Nephrol. 2004;62:229-33.

5. Akilesh S, Alem A, Nicosia RF. Combined crystalline podocytopathy and tubulopathy associated with multiple myeloma. Hum Pathol. 2014;45:875-9.

6. Korbet SM, Schwartz MM. Multiple myeloma. J Am Soc Nephrol. 2006;17:2533-45.

7. Kyle RA. Multiple myeloma: review of 869 cases. Mayo Clin Proc. 1975;50:29-40.

8. Markowitz GS. Dysproteinemia and the kidney. Adv Anat Pathol. 2004;11:49-63.

9. Keller LS, Faull RJ, Smith P, Swift J, Bannister KM, Otto S, et al. Crystalloid deposits in the kidney. Nephrology (Carlton). 2005;10:81-3. 
10. Papla B, Spólnik P, Rzenno E, Zduńczyk A, Rudzki Z, Okoń K, et al. Generalized crystal-storing histiocytosis as a presentation of multiple myeloma: a case with a possible pro-aggregation defect in the immunoglobulin heavy chain. Virchows Arch. 2004:445:83-9.

11. Yamamoto T, Hishida A, Honda N, Ito I, Shirasawa H, Nagase M. Crystal-storing histiocytosis and crystalline tissue deposition in multiple myeloma. Arch Pathol Lab Med. 1991;115:351-4.

12. Herlitz LC, D'Agati VD, Markowitz GS. Crystalline nephropathies. Arch Pathol Lab Med. 2012;136:713-20.

13. Stompór T, Perkowska-Ptasińska A, Wojciechowska M, Zając K, ChmielewskaBadziąg A, Pawłowska A. Unusual manifestation of crystalline light chain tubulopathy in patient with multiple myeloma: case report and review of the literature. Ren Fail. 2014;36:795-9.

14. Messiaen T, Deret S, Mougenot B, Bridoux F, Dequiedt P, Dion JJ, et al. Adult Fanconi syndrome secondary to light chain gammopathy. Clinicopathologic heterogeneity and unusual features in 11 patients. Medicine (Baltimore). 2000;79:135-54

15. Leboulleux M, Lelongt B, Mougenot B, Touchard G, Makdassi R, Rocca A, et al. Protease resistance and binding of lg light chains in myelomaassociated tubulopathies. Kidney Int. 1995;48:72-9.

16. Eyre J, loannou K, Grubb BD, Saleem MA, Mathieson PW, Brunskill NJ, et al. Statin-sensitive endocytosis of albumin by glomerular podocytes. Am J Physiol Renal Physiol. 2007;292:F674-81.

17. Sandoval RM, Wagner MC, Patel M, Campos-Bilderback SB, Rhodes GJ, Wang E, et al. Multiple factors influence glomerular albumin permeability in rats. J Am Soc Nephrol. 2012;23:447-57.

18. Carson JM, Okamura K, Wakashin H, McFann K, Dobrinskikh E, Kopp JB, et al. Podocytes degrade endocytosed albumin primarily in lysosomes. PLoS One. 2014;9, e99771.

19. De S, Kuwahara S, Saito A. The endocytic receptor megalin and its associated proteins in proximal tubule epithelial cells. Membranes (Basel). 2014:4:333-55

20. Nasr SH, Preddie DC, Markowitz GS, Appel GB, D'Agati VD. Multiple myeloma, nephrotic syndrome and crystalloid inclusions in podocytes. Kidney Int. 2006;69:616-20.

21. Kowalewska J, Tomford RC, Alpers CE. Crystals in podocytes: an unusual manifestation of systemic disease. Am J Kidney Dis. 2003;42:605-11.

22. Matsuyama N, Joh K, Yamaguchi Y, Aizawa S, Kanai T, Kitajima T, et al. Crystalline inclusions in the glomerular podocytes in a patient with benign monoclonal gammopathy and focal segmental glomerulosclerosis. Am J Kidney Dis. 1994;23:859-65.

23. Carstens PH, Woo D. Crystalline glomerular inclusions in multiple myeloma. Am J Kidney Dis. 1989;14:56-60.

24. Elliott MR, Cortese C, Moreno-Aspitia A, Dwyer JP. Plasma cell dyscrasia causing light chain tubulopathy without Fanconi syndrome. Am J Kidney Dis. 2010;55:1136-41.

25. Dingli D, Larson DR, Plevak MF, Grande JP, Kyle RA. Focal and segmental glomerulosclerosis and plasma cell proliferative disorders. Am J Kidney Dis. 2005;46:278-82.

26. Stewart CJ, Spagnolo DV. Crystalline plasma cell inclusions in helicobacterassociated gastritis. J Clin Pathol. 2006;59:851-4.

27. Levine SB, Bernstein LD. Crystalline inclusions in multiple myeloma. JAMA. 1985:254:1985.

\section{Submit your next manuscript to BioMed Central and we will help you at every step:}

- We accept pre-submission inquiries

- Our selector tool helps you to find the most relevant journal

- We provide round the clock customer support

- Convenient online submission

- Thorough peer review

- Inclusion in PubMed and all major indexing services

- Maximum visibility for your research 